\title{
Anatomical Study on the Psoas Minor Muscle in Human Fetuses
}

\author{
Estudio Anatómico del Músculo Psoas Menor en Fetos Humanos \\ "Danilo Ribeiro Guerra; **Francisco Prado Reis; "***Afrânio de Andrade Bastos; \\ ***** Ciro José Brito; ${ }^{* * * * *}$ Roberto Jerônimo dos Santos Silva \& ****José Aderval Aragão
}

GUERRA, D. R.; REIS, F. P.; BASTOS, A. A.; BRITO, C. J.; SILVA, R. J. S. \& ARAGÃO, J. A. Anatomical study on the psoas minor muscle in human fetuses. Int. J. Morphol., 30(1):136-139, 2012.

SUMMARY: The anatomy of the psoas minor muscle in human beings has frequently been correlated with ethnic and racial characteristics. The present study had the aim of investigating the anatomy of the psoas minor, by observing its occurrence, distal insertion points, relationship with the psoas major muscle and the relationship between its tendon and muscle portions. Twenty-two human fetuses were used (eleven of each gender), fixed in $10 \%$ formol solution that had been perfused through the umbilical artery. The psoas minor muscle was found in eight male fetuses: seven bilaterally and one unilaterally, in the right hemicorpus. Five female fetuses presented the psoas minor muscle: three bilaterally and two unilaterally, one in the right and one in the left hemicorpus. The muscle was independent, inconstant, with unilateral or bilateral presence, with distal insertions at different anatomical points, and its tendon portion was always longer than the belly of the muscle.

KEY WORDS: Psoas Muscles; Muscle, Skeletal; Anatomy; Gender Identity.

\section{INTRODUCTION}

When the psoas minor muscle is present in humans, it is located in the posterior wall of the abdomen, laterally to the lumbar spine and in close contact and anteriorly to the belly of the psoas major muscle (Van Dyke et al., 1987; Domingo, Aguilar et al., 2004; Leão et al., 2007). Although its function is considered to be extremely subtle, it aids in flexing the spine and, in cases in which its fibers are joined to those of the psoas major, it aids in flexing the hips (Pellegrino et al., 1998). Anatomical studies on the psoas minor muscle have revealed that ethnic and racial characteristics have a large influence on the frequency of its presence in human beings. Snell (1999) and Donovan et al. (1981) observed that it was absent in $40 \%$ of the cases analyzed. Not only can the frequency of its presence vary, but also its morphology. According to Testut \& Latarjet (1976), it is not rare to find the psoas minor muscle reduced to only one or two tendons. In a description by Gardner $e t$ al. (1988), they reported that this muscle was inserted by means of a thin tendon, into the iliopectineal eminence and into the arched line, and that it had an additional inconstant insertion into the iliac fascia and pectineal ligament.
The aim of the present study was to investigate the anatomy of the psoas minor muscle in human fetuses: establishing the frequency of its occurrence according to sex; ascertaining the distal insertion points; analyzing the possible dependent relationship between the fibers of the psoas minor and psoas major muscles; and determining the proportional relationship between the tendon and muscle parts of the psoas minor.

\section{MATERIAL AND METHOD}

Twenty-two human fetuses of approximately seven to nine months of age were dissected. These had been fixed and kept for more than one year in $10 \%$ formol solution that had been perfused through the umbilical artery. The fetuses belonged to the Anatomy Laboratory of Tiradentes University, and were used in accordance with Law 8501, of November 30, 1992, which makes provisions regarding the use of unclaimed cadavers for the purposes of scientific study

\footnotetext{
* Adjunct Professor of Human Anatomy, Federal University of Sergipe (UFS), Aracaju, Sergipe, Brazil.

** Titular Professor, Medical School of Tiradentes University (UNIT), Aracaju, Sergipe, Brazil.

*** Associate Professor in the Department of Physical Education, Federal University of Sergipe (UFS), Aracaju, Sergipe, Brazil.

***** Adjunct Professor in the Department of Physical Education, Federal University of Sergipe (UFS), Aracaju, Sergipe, Brazil.

${ }^{* * * * * *}$ Assistant Professor in the Department of Physical Education, Federal University of Sergipe (UFS), Aracaju, Sergipe, Brazil.
} 
or research. A xiphopubic incision was made in the abdominal cavity in association with Pfanenstiel and the entire small and large intestine was resected. The data obtained were recorded on a specific form and photographs were taken using an Olympus digital camera.

\section{RESULTS}

Out of the 22 fetuses that were dissected, the psoas minor muscle was present in $13(59.09 \%)$. Among these, it was present bilaterally in ten (Fig. 1) and unilaterally in three (Fig.2). The distribution of the psoas minor muscle was analyzed according to sex and side of the body (Fig. 3).

The muscle fibers of the psoas minor always originated directly from the body of the 12 th thoracic vertebra

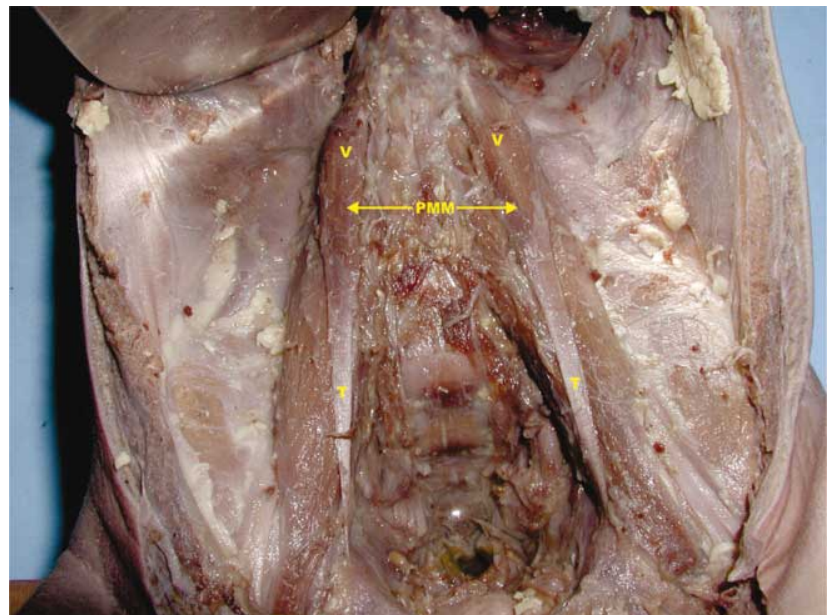

Fig. 1. Bilateral psoas minor muscle. Legend: $\mathrm{T}$ - tendon; V muscle belly; PMM - Psoas minor muscle.

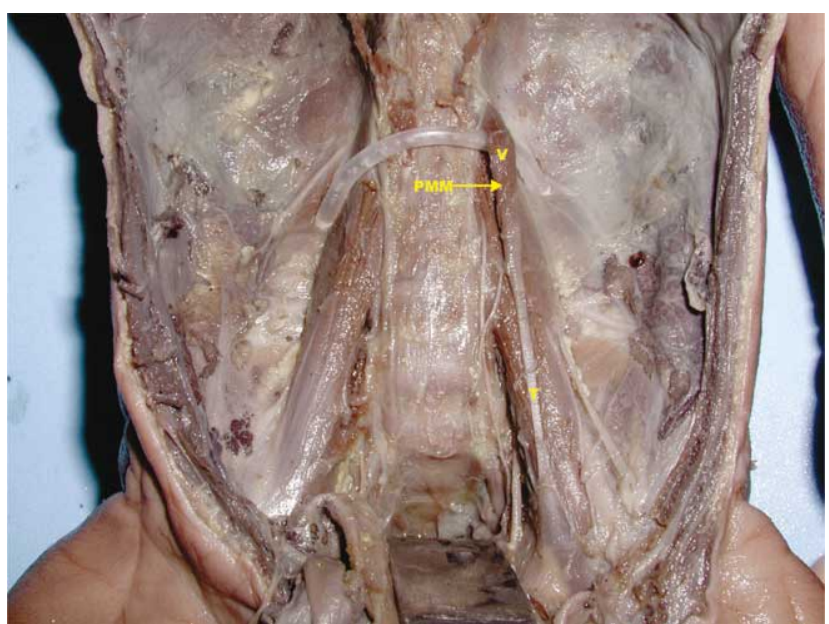

Fig. 2. Unilateral psoas minor muscle. Legend: $\mathrm{T}$ - tendon; $\mathrm{V}-$ muscle belly; PMM - Psoas minor muscle. and the underlying intervertebral disc. These fibers were not seen to arise as ramifications of the fibers of the psoas major. The length of the tendon portion of the psoas minor muscle was proportionally greater than the length of the muscle portion (Fig. 4). On average, the tendon represented $57 \%$ of the total length of the muscle: $60 \%$ for females and $54 \%$ for males.

The distal insertion occurred in the iliopubic eminence, arched line or pectineal line, or simultaneously in all three anatomical points (Fig. 5). In some cases, the tendon of the psoas minor muscle presented fanlike expansion that joined it to the fascia of the psoas major muscle, such that the two structures could not be distinguished from each other macroscopically.

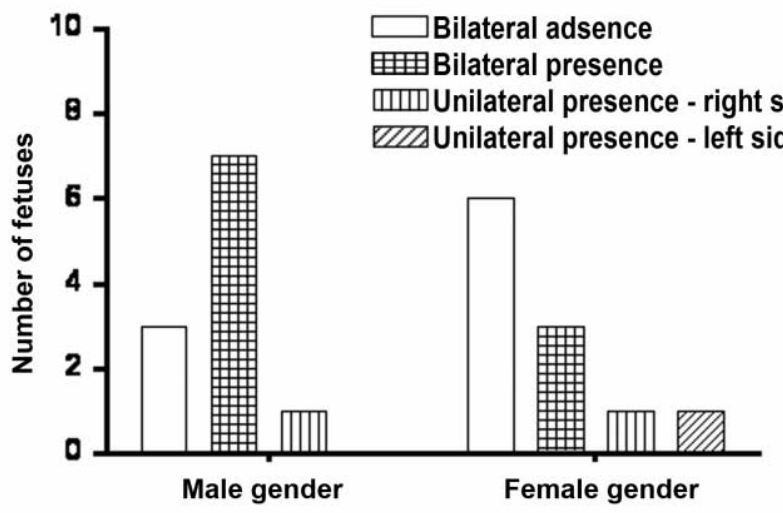

Fig. 3. Distribution of the psoas minor muscle in human fetuses, according to sex and side of the body.

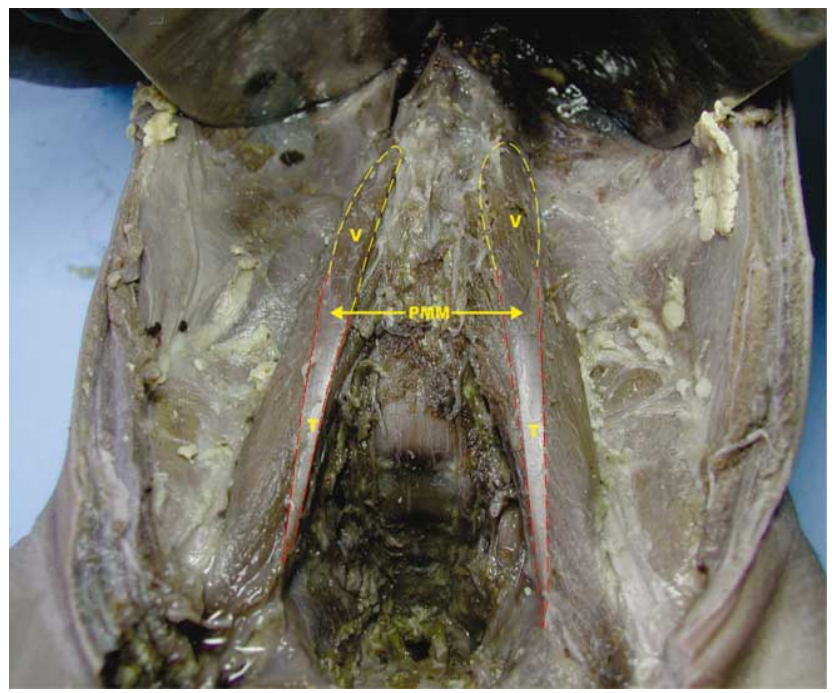

Fig. 4. View of the relationship between muscle and tendinous portions of the psoas minor muscle. Legend: $\mathrm{T}$ - tendon; $\mathrm{V}$ - muscle belly; PMM - Psoas minor muscle. 


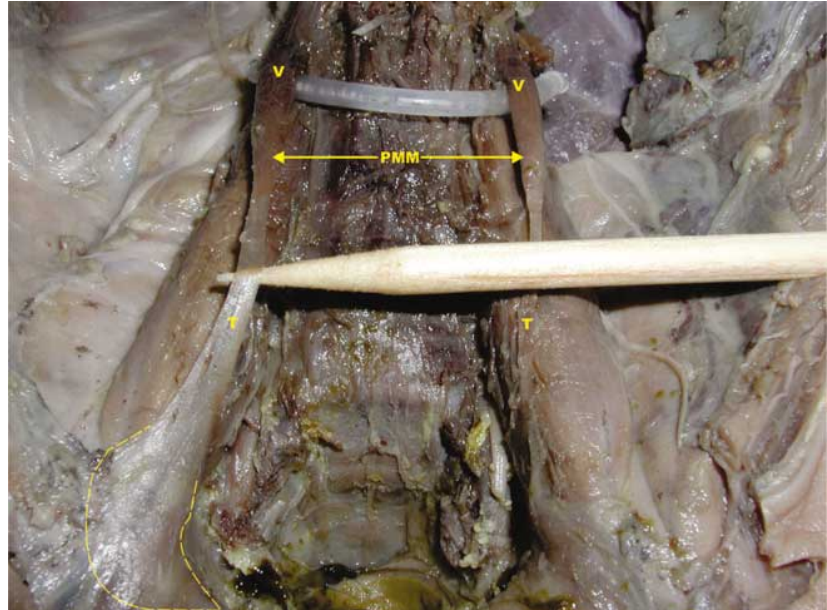

Fig. 5. Distal area of insertion of the psoas minor muscle corresponding to the iliopubic eminence, arched line and pectineal line. Legend: T - tendon; V - muscle belly; PMM - Psoas minor muscle.

\section{DISCUSSION}

In the present study, the psoas minor muscle was present in approximately 59\% of the human fetuses. This proportion is very similar to what was described by Snell, who found the muscle in $60 \%$ of the cases studied. According to Kraychete et al. (2007), the psoas minor muscle was present in only $30 \%$ of the cases. Regarding sex, there was no significant difference.

No data on the proportional relationship between the muscle and tendon parts of the psoas minor muscle were found in the literature, which made it impossible to do a comparative analysis on the findings. Even so, there have been descriptions noting that the tendon of this muscle was very long (Lee et al., 1989; Téllez \& Acuña, 1998). This affirmation corroborates the data of the present study, in which on average, the tendon represented $57 \%$ of the total length of the muscle, with similar values for both sexes.

Differing from the findings of Testut \& Latarjet, there were no cases in which more than one tendon of the psoas minor muscle was found. In all the cases studied, the muscle only presented a single tendon.

In all the fetuses of the present study, the fibers of the psoas minor muscle originated in the bodies of the $12^{\text {th }}$ thoracic vertebra and the underlying intervertebral disc, as also found by Lee et al. and Torres et al. (1995). However, in no case was it found that the fibers of the psoas minor muscle originated as a ramification of the fibers of the psoas major. This type of occurrence was described in some cases by Macalister (1875).
In our study, the two muscles always presented differentiated and independent origins for their fibers.

In four fetuses, the psoas minor passed posteriorly to the crural arch and was then inserted into the pectineal line of the femur, which is in agreement with some cases described by Bankart et al. (1869). In addition to this fixation point, insertions consisting of a thin tendon were observed in the iliopectineal eminence, arched line, pectineal line, iliac fascia and pectineal ligament. The muscle was, in many cases, found to have insertions in more than one of these points, and this was also found by Muttarak \& Peh (2000). Gardner et al. described the possibility of insertion of the muscle at these sites, with the exception of the pectineal line.

The psoas minor was an independent inconstant muscle, with unilateral or bilateral presence and with distal insertions at different anatomical points, and its tendon portion was always longer than the belly of the muscle.

GUERRA, D. R.; REIS, F. P.; BASTOS, A. A.; BRITO, C. J.; SILVA, R. J. S. \& ARAGÃO, J. A. Estudio anatómico del músculo psoas menor en fetos humanos. Int. J. Morphol., 30(1):125129, 2012.

RESUMEN: La anatomía del músculo psoas menor, en los seres humanos ha sido a menudo vinculada con cuestiones de orden étnico-raciales. Este estudio tuvo como objetivo evaluar la anatomía del músculo psoas menor en relación a su presencia, puntos de origen e inserción, relación con el músculo psoas mayor y sus porciones tendinosa y muscular. Se utilizaron 22 fetos humanos (11 de cada sexo) que fueron fijados en solución de formalina al $10 \%$ por perfusión a través de la arteria umbilical. El músculo psoas menor se encontró en 8 fetos de sexo masculino, siete bilateralmente y apenas uno unilateralmente en el hemicuerpo derecho. En los fetos de sexo femenino, cinco tenían el músculo psoas menor, tres bilateralmente y dos unilateralmente, siendo uno encontrado en el hemicuerpo derecho y otro en el izquierdo. El músculo es independiente, inconstante, de presencia unilateral o bilateral, con la inserción en diferentes sitios anatómicos y su porción tendinosa siempre mayor que el vientre muscular

PALABRAS CLAVE: Músculos psoas menor; Músculo esquelético; Anatomía; Identidad de sexo.

\section{REFERENCES}

Bankart, J.; Pye-Smith, P. H \& Phillips, J. J. Notes of abnormalities observed in the dissecting room during the winter sessions of 1866-7 and 1867-8. Guy's Hosp. Rep., 14:436-55, 1869.

Domingo, V.; Aguilar, J. L. \& Pelaez, R. Bloqueos nerviosos periféricos de La extremidad inferior para analgesia postoperatoria y tratamiento del dolor crónico. Rev. Soc. Esp. Dolor, 11:61-75, 2004. 
Donovan, P. J.; Zerhouni, E. A. \& Siegelman, S. S. cT of the psoas compartment of the retroperitoneum. Semin. Roentgenol., 16:241-50, 1981 .

Gardener, E.; Gray, D. J. \& O'rahilly, R. O abdome. In: Gardener, E.; Gray, D. J. \& O'Rahilly, R. Anatomia. Parede abdominal posterior. $4^{\mathrm{a}}$ ed. Rio de Janeiro, Guanabara Koogan, 1988. p.356.

Kraychete, D. C.; Rocha, A. P. \& Castro, P. A. Psoas muscle abscess after epidural analgesia: case report. Rev. Bras. Anestesiol., 57:195-8, 2007.

Leão, A. R. S.; Amaral, R. P. G.; Abud, T. G.; Demarchi, G. T. S.; Freire Filho, E. O. \& Novack, P. R. Patologias do compartimento iliopsoas: avaliação radiológica. Radiol. Bras., 40:26772, 2007.

Lee, J. K.; Sagel, S. S. \& Stanley, R. J. Computed body tomography with MRI correlation. New York, Raven, 1989. pp.746-50.

Macalister, A. Additional observations on muscular anomalies in human anatomy (third series), with a catalogue of the principal muscular variations hitherto published. Trans. Roy. Irish. Acad., 25:1-130, 1875.

Muttarak, M. \& Peh, W. C. CT of unusual iliopsoas compartment lesions. Radiographics, 20:S53-66, 2000.

Pellegrino, F.; Tangelson, C. \& Galliano, L. Criterios de homologacion entre lãs cinturas escapular y pélvica y sus estructuras asociadas. Rev. Chil. Anat., 16:75-82, 1998.

Snell, R. S. O membro inferior. In: Snell, R. S. Anatomia clinica para estudantes de medicina. $5^{\mathrm{a}}$ ed. Rio de Janeiro, Guanabara Koogan, 1999. p.149.

Téllez, V. S. \& Acuña, L. E. B. Consideraciones anatómicas de los músculos inconstantes. MedUNAB, 1:165-70, 1998.

Testut, L. \& Latarjet, A. Músculos del abdomen: región posterior o lumboiliaca. Tratado de anatomía humana. $9^{\mathrm{a}}$ ed. Barcelona, Salvat, 1976. p.980.

Torres, G. M.; Cernigliaro, J. G.; Abbitt, P. L.; Mergo, P. J.; Hellein, V. F.; Fernandez, S. \& Ros, P. R. Iliopsoas compartment: normal anatomy and pathologic processes. Radiographics, 15:1285-97, 1995.

Van Dyke, J. A.; Holley, H. C. \& Anderson, S. D. Review of iliopsoas anatomy and pathology. Radiographics, 7:53-84, 1987.

\author{
Correspondence to: \\ José Aderval Aragão \\ Rua Aloisio Campos 500 \\ Bairro Atalaia \\ Aracaju \\ Sergipe \\ CEP: 49035-020 \\ BRAZIL
}

Tel: 79 - 9191-6767

Email: jaafelipe@infonet.com.br

Received: 18-06-2011

Accepted: 27-09-2011 